\title{
Highly Sensitive N-(1-Naphthyl)Ethylene Diamine Method for the Spectrophotometric Determination of Trace Amounts of Nitrite in Various Water Samples
}

\section{Padmarajaiah Nagaraja, Mattighatta Shivaswamy \& Hemantha Kumar}

To cite this article: Padmarajaiah Nagaraja , Mattighatta Shivaswamy \& Hemantha Kumar (2001) Highly Sensitive N-(1-Naphthyl)Ethylene Diamine Method for the Spectrophotometric Determination of Trace Amounts of Nitrite in Various Water Samples, International Journal of Environmental Analytical Chemistry, 80:1, 39-48, DOI: $10.1080 / 03067310108044384$

To link to this article: https://doi.org/10.1080/03067310108044384

曲 Published online: 04 Oct 2006.

Submit your article to this journal ๘

山ll Article views: 61

Q View related articles $\asymp$

Citing articles: 5 View citing articles $\sqsubset$ 


\title{
HIGHLY SENSITIVE N-(1-NAPHTHYL)ETHYLENE DIAMINE METHOD FOR THE SPECTROPHOTOMETRIC DETERMINATION OF TRACE AMOUNTS OF NITRITE IN VARIOUS WATER SAMPLES
}

\author{
PADMARAJAIAH NAGARAJA ${ }^{\mathrm{a}^{*}}$, MATTIGHATTA SHIVASWAMY $Y^{\mathrm{b}}$ and \\ HEMANTHA KUMAR ${ }^{b}$ \\ ${ }^{a}$ Department of Chemistry and ${ }^{b}$ Department of Environmental Science, University of \\ Mysore, Manasagangothri, Mysore-570 006, India
}

(Received 28 Septembre 2000; In final form 28 February 2001)

\begin{abstract}
A rapid, simple, sensitive and selective spectrophotometric determination of trace nitrite is described. The method is based on a diazotization-coupling reaction between dapsone and $\mathrm{N}$-(1-naphthyl)ethylenediamine dihydrochloride (NEDA) in a hydrochloric acid medium. The molar absorptivity and Sandell's sensitivity were found to be $7.2 \times 10^{4} 1 \mathrm{~mol}^{-1} \mathrm{~cm}^{-1}$ and $0.00063 \mu \mathrm{g} \mathrm{ml}^{-1}$, respectively. The calibration graph is linear for $0.002-0.6 \mu \mathrm{g} \mathrm{ml}^{-1}$ of nitrite. The interference effects of various cations and anions were also studied and reported. This method has been found to be applicable to the determination of nitrite in various water samples.
\end{abstract}

Keywords: Dapsone; N-(1-naphthyl)ethylenediamine dihydrochloride; nitrite; spectrophotometry

Nitrite is undesirable in water due to its toxicity ${ }^{[1]}$, hence a great deal of interest has been generated concerning potential health hazards of nitrites. Nitrites are frequently used as preservatives in food products and their precursors are widely distributed in nature because of nitrogen fertilizers ${ }^{[2]}$. They oxidize haemoglobin to methemoglobin, which is unable to transport oxygen ${ }^{[3]}$, and they react with amines and amides to form nitrosamines, which are potent carcinogenes ${ }^{[4,5]}$. Nitrite concentrations in fresh water are usually very low, $0.001 \mathrm{mg} / 1 \mathrm{NO}_{2}-\mathrm{N}$, and rarely higher than $1 \mathrm{mg} / \mathrm{NO}_{2}-\mathrm{N}^{[6]}$. High nitrite concentrations are generally indicative of industrial effluents, and are often associated with an unsatisfactory microbiological quality of water. The maximum permissible limit in potable water is fixed by the U.S public health service at $0.06 \mu \mathrm{g} \mathrm{ml}^{-1[7]}$. In view of the ubiquitous presence of nitrite in the environment, a sensitive and selective method for a trace-level determination of nitrite is desirable.

\footnotetext{
* Corresponding author. Fax: +91-821-518835. E-mail: nagarajap@mailcity.com
} 
Nitrite has been determined by chemiluminescence ${ }^{[8]}$, fluorometry ${ }^{[9]}$, polarography ${ }^{[10]}$ and Raman spectroscopy ${ }^{[11]}$. Although these methods are quite sensitive, they have several limitations. These methods are difficult, time consuming and require fairly sophisticated equipment. Recently, many papers have been published on the determination of nitrite based on its catalytic effect on the oxidation of organic compounds by bromate ${ }^{[12-14]}$ or hydrogen peroxide ${ }^{[15]}$. These methods are highly sensitive, but suffer from careful control of the temperature and strong interference from sulphide, iodide, thiocyanate, vanadium and iron salts. Although nitrites can be determined by the above mentioned methods, the classical methods are spectrophotometric procedures. Several authors ${ }^{[16,17]}$ have proposed flow-injection analysis for determining nitrite through the formation of azo dyes. Most spectrophotometric methods for the determination of nitrite in natural and waste water were based on the Griess-Ilosvey reaction ${ }^{[18]}$, which was modified several times. Modifications by Saltzman ${ }^{[19]}$ and Jacobs-Hochheiser ${ }^{[20]}$ are widely used and have been adapted as standard procedures ${ }^{[21]}$. Although methods based on reactions other than diazocoupling reactions have also been developed for the determination of nitrite ${ }^{[22,23]}$, they are prone to problems of sensitivity and a lack of selectivity, mainly due to interference. The spectrophotometric determination of nitrite in various samples by diazotization-coupling techniques ${ }^{[24-26]}$ is a very important and common analysis. A thorough literature survey revealed that in most of the diazotization coupling reaction, NEDA is used as a coupling reagent with various diazotizing agents. NEDA is advantageous as a coupling agent because it is colourless, readily soluble in water and couples in a fairly acidic solution, also unlike 1-naphthylamine, it is non-carcinogenic. It was the purpose of this work to introduce for the first time dapsone as a new substrate for diazotization coupling reactions and NEDA as a coupling agent for the determination of nitrite in various water samples. Diazotized dapsone coupled with NEDA in an acid medium gives an intense pink colour azo dye. The main advantage of the present procedure is its greater sensitivity and selectivity than some recently reported methods ${ }^{[27-30]}$.

\section{EXPERIMENTAL}

\section{Reagents and chemicals}

All the chemicals used were of analytical reagent grade and double-distilled water was used throughout the experiments. A $1 \mathrm{mg} / \mathrm{ml}$ stock solution of nitrite was prepared by dissolving $150 \mathrm{mg}$ of pre-dried sodium nitrite in $100 \mathrm{ml}$ of dem- 
ineralized water. A small amount of chloroform was added as a stabiliser. Working standards were prepared by appropriate dilution of the stock solution. A $0.1 \%$ solution in 5\% ethanol was prepared from recrystallized dapsone (Sigma). A $0.5 \%$ solution in water of NEDA (Sigma) was used. Hydrochloric acid, $1 \mathrm{M}$ was used.

\title{
Apparatus
}

A JASCO Model UVIDEC610 spectrophotometer with a $1.0 \mathrm{~cm}$ matched cell was used for electronic spectral measurements.

\section{Procedure}

A solution containing $0.05-15 \mu \mathrm{g}\left(0.002-0.6 \mu \mathrm{g} \mathrm{ml}^{-1}\right)$ of nitrite was transferred into a series of $25 \mathrm{ml}$ calibrated flasks to which $2.0 \mathrm{ml}$ of dapsone, $1.0 \mathrm{ml}$ of $1 \mathrm{M}$ hydrochloric acid were added; the mixture was allowed to stand 2 min for diazotization. Then, $1.0 \mathrm{ml}$ of NEDA was added. The maximum pink colour developed within $5 \mathrm{~min}$ and the absorbance was measured at $540 \mathrm{~nm}$ against a reagent blank and a calibration graph was constructed.

\section{Sample preparation}

A sample taken for the determination of nitrite should be collected in glass or polyethylene bottles. $100 \mathrm{ml}$ of water sample were placed in a beaker and $3 \mathrm{ml}$ of $1 \%$ mercuric chloride solution were added. After $5 \mathrm{~min}$, were filtered to remove any sulphides and iodide present. A known volume of the filtrate was analysed by the above procedure.

\section{RESULTS AND DISCUSSION}

\begin{abstract}
Absorption spectra
When NEDA was added to the colourless diazotized dapsone in a hydrochloric acid medium, an intense pink azo dye was obtained. The absorption spectrum of the pink dye showed maximum absorption at $540 \mathrm{~nm}$. Under the recommended conditions the dye was stable for $50 \mathrm{~h}$, and absorbance varied by not more than $2 \%$ over a period of seven days. Figure 1 illustrates the absorption spectra of this pink azo dye and a colourless reagent blank.
\end{abstract}




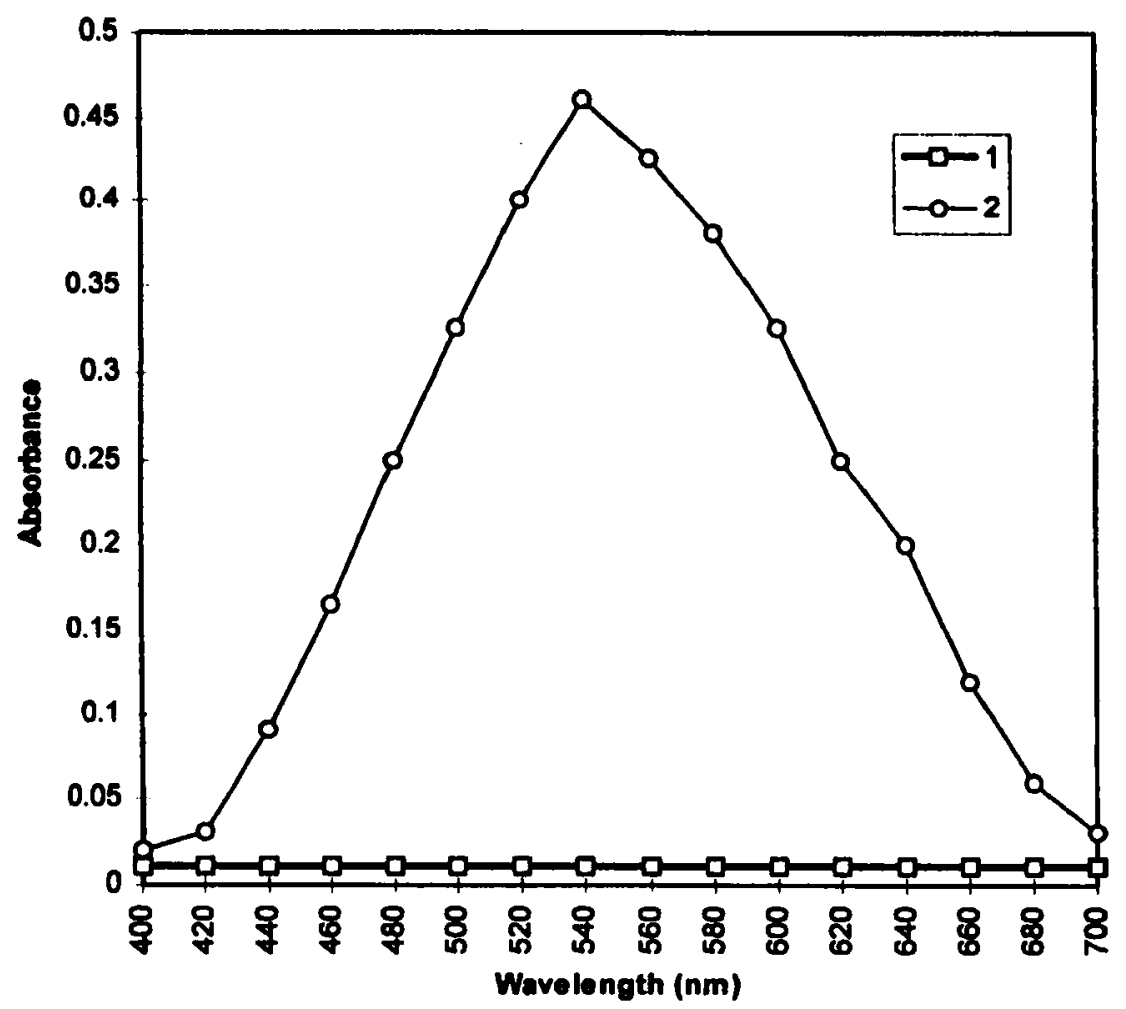

FIGURE 1 Absorption spectra of the reaction product of $\left(\mathrm{NO}_{2}^{-} 0.3 \mu \mathrm{g} \mathrm{ml}{ }^{-1}\right)$ 1. Dapsone + NEDA (Reagent Blank); 2. Nitrite + Dapsone + NEDA system

\section{Reaction conditions}

When no acid is present, diazotization does not take place. The effect of acidity on the diazotization was studied. The use of hydrochloric acid as the reaction medium was found to give the better results than use of sulphuric acid medium for diazotization. A hydrochloric acid concentration of at least $1.0 \mathrm{ml}$ of $1 \mathrm{M}$ was found necessary for complete diazotization. A $0.5-6.0 \mathrm{ml}$ of $1 \mathrm{M}$ hydrochloric acid range gave constant absorbance.

With NEDA as a coupling agent, new sulfa compounds, like sulfathiazole, sulfacetamide, sulfadiazine, sulfamethaoxozole and dapsone, were tested as a new substrate for diazotization, but only dapsone gave a maximum sensitive and a highly selective reaction under the conditions for the determination. We found that NEDA in acidic medium was such an excellent coupling agent that we did not conduct any experiments with other coupling agents. The effects of NEDA 
and the dapsone concentration on the colour intensity was studied by using a fixed nitrite concentration and varying NEDA and dapsone concentrations. The results showed that the use of $1-4 \mathrm{ml}$ of $0.5 \%$ NEDA and $1-4 \mathrm{ml}$ of $0.1 \%$ dapsone gave a constant and maximum absorbance. Therefore, the use of $1.0 \mathrm{ml}$ of NEDA and $2 \mathrm{ml}$ of dapsone were recommended.

\section{Colour stability}

Under the optimized conditions, although the pink colour develops instantaneously, 5 min is sufficient to obtain the maximum and constant absorbance. The dye showed no change in absorbance in $50 \mathrm{~h}$. The absorbance remained constant at $10-50^{\circ} \mathrm{C}$.

\section{Reaction sequence and stoichiometry}

For the diazotization process, it would be expected that two $\mathrm{NH}_{2}$ groups in dapsone would be readily diazotized in a hydrochloric acid medium, and that each diazonium group would then react with a molecule of NEDA by electrophilic substitution at 4-position to produce an intense pink azo dye. An investigation of the continuous variation method of diazotized dapsone and NEDA showed that diazotized dapsone interacts with NEDA in the ratio of 1:2. Similar results have been observed with the mole-ratio method. For reaction sequence based on the above results, refer to scheme 1 .

\section{Analytical characteristics}

The colour system was found to obey Beer's Law in the range of 0.05-15 $\mu \mathrm{g}$ of nitrite per $25 \mathrm{ml}\left(0.002-0.6 \mu \mathrm{g} \mathrm{ml}^{-1}\right)$ of the dapsone-NO ${ }_{2}^{-}-\mathrm{NEDA}^{-}$system. The molar absorptivity and Sandell's sensitivity were found to be $7.2 \times 10^{4} 1 \mathrm{~mol}^{-1}$ $\mathrm{cm}^{-1}$ and $0.00063 \mu \mathrm{g} \mathrm{cm}^{-2}$ respectively. The optimum concentration range evaluated by Ringbom's method was found to be between $0.02-0.5 \mu \mathrm{g} \mathrm{ml}^{-1}$ for log $\mathrm{Io} / \mathrm{I}=\mathbf{0 . 0 0 1}$. The standard deviation and relative standard deviation were found to be \pm 0.005 and $1.20 \%$ for $0.3 \mu \mathrm{g} \mathrm{ml}^{-1}$ of nitrite, respectively.

\section{Effects of diverse ions}

The interference from foreign ions commonly present in water was studied by adding known amounts of foreign species to a solution containing $0.3 \mu \mathrm{g} \mathrm{ml}^{-1}$ of nitrite by this method (Table I). Sulphide and Iron (III), can be masked up to 400 and $200 \mu \mathrm{g} \mathrm{ml}^{-1}$ by the addition of $1 \mathrm{ml}$ of $1 \%$ mercuric chloride and $3 \mathrm{ml}$ of $5 \%$ EDTA, respectively. 

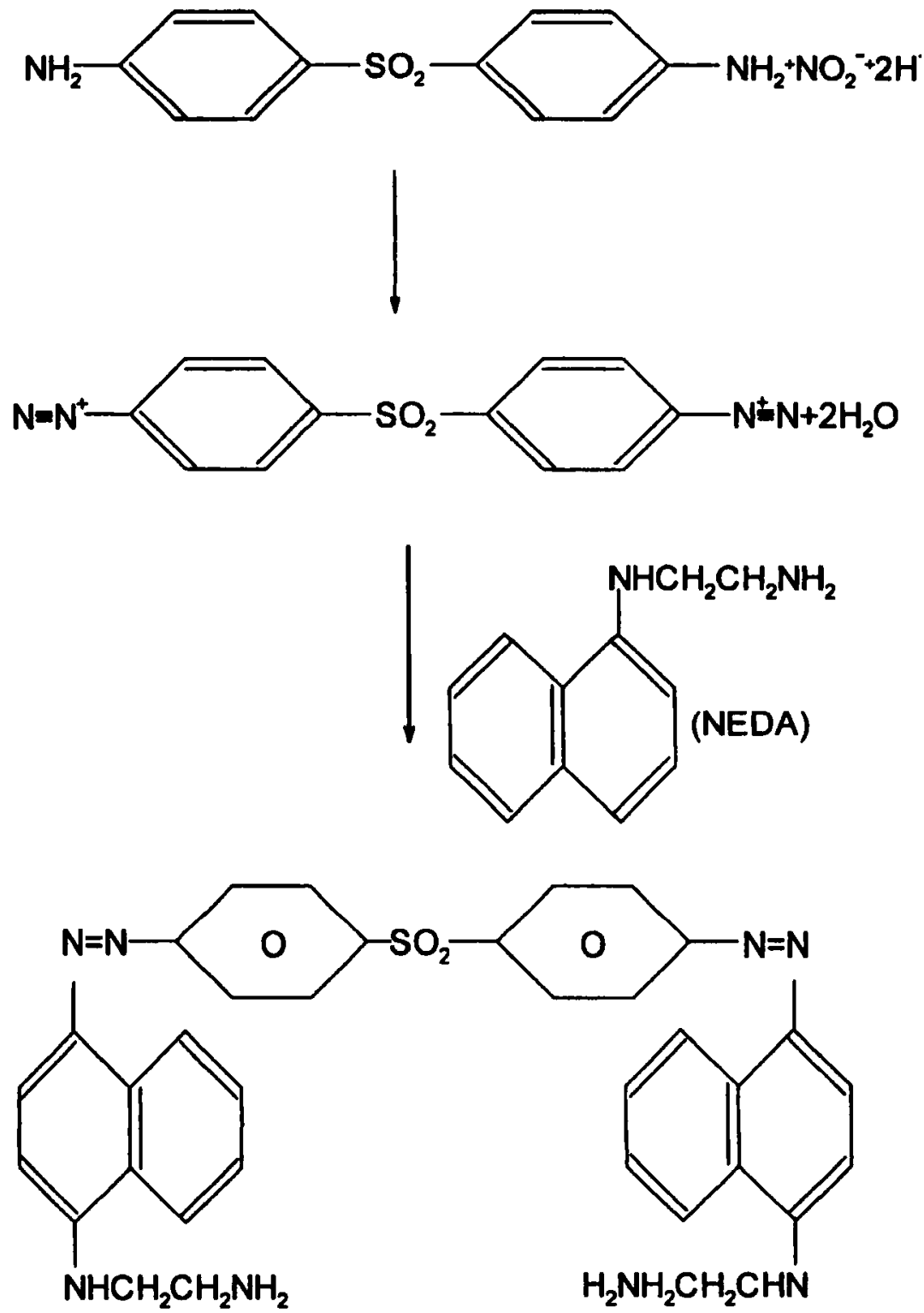

SCHEME 1 Reaction of NEDA with diazotized dapsone 
TABLE I Effect of diverse species on the determination of $\left(0.3 \mu \mathrm{g} \mathrm{ml}^{-1}\right)$ nitrite

\begin{tabular}{lc}
\hline \multicolumn{1}{c}{ Foreign ions } & Tolerance limit $\left(\mu \mathrm{g} \mathrm{m}^{-1}\right)$ \\
\hline $\mathrm{NO}_{3}{ }^{-}, \mathrm{Cl}^{-}, \mathrm{EDTA}$ & 10000 \\
$\mathrm{~K}^{+}, \mathrm{Cd}^{2+}, \mathrm{CH}_{3} \mathrm{COO}^{-}, \mathrm{Ca}^{2+}, \mathrm{CO}_{3}{ }^{2-}, \mathrm{SO}_{4}{ }^{2-}, \mathrm{Na}^{+}, \mathrm{Mg}^{2+}$ & 5000 \\
$\mathrm{Al}^{3+}, \mathrm{WO}_{4}{ }^{2+}, \mathrm{Ba}^{2+}, \mathrm{Tartarate}^{\mathrm{PO}_{4}{ }^{3-}}$ & 4000 \\
$\mathrm{SO}_{3}{ }^{2-}, \mathrm{Mn}^{2+}, \mathrm{CN}^{-}, \mathrm{Hg}^{2+}, \mathrm{SCN}^{-}$ & 2000 \\
$\mathrm{I}^{-}, \mathrm{F}^{-}$ & 1000 \\
$\mathrm{~S}^{2-\mathrm{a}}$ & 400 \\
$\mathrm{~Pb}^{2+}, \mathrm{MoO}_{4}{ }^{2+}, \mathrm{Ni}^{2+}, \mathrm{Zn}^{2+}$ & 200 \\
$\mathrm{Fe}^{2+}, \mathrm{Co}^{2+}, \mathrm{Cu}^{2+}, \mathrm{Sn}^{2+}$ & 40 \\
$\mathrm{Fe}^{3+\mathrm{b}}, \mathrm{V}^{5+}, \mathrm{Cr}\left(\mathrm{VI}^{2+}\right.$ & 8 \\
\hline
\end{tabular}

a. Can be masked up to $400 \mu \mathrm{g} \mathrm{ml}^{-1}$ by the addition of $1 \mathrm{ml}$ of $1 \% \mathrm{HgCl}_{2}$.

b. Can be masked up to $120 \mu \mathrm{g} \mathrm{ml}^{-1}$ by the addition of $3 \mathrm{ml}$ of $5 \%$ EDTA.

\section{Application}

In order to assess the validity of the method, samples were collected from different sources and treated with mercuric chloride to remove any sulphide and as a preservative. The samples were analysed by the proposed and reported method (Table II) and the results are in good agreement. The method was also compared to reported spectrophotometric methods, which employed NEDA as a coupling agent and found to be more sensitive (Table III).

TABLE II Determination of nitrite in various water samples

\begin{tabular}{|c|c|c|c|c|c|}
\hline \multirow[b]{2}{*}{ Sample } & \multirow[b]{2}{*}{$\begin{array}{c}\text { Nitrite added } \\
(\mu g)\end{array}$} & \multicolumn{2}{|c|}{ Proposed Method } & \multicolumn{2}{|c|}{ Reported Method ${ }^{[19]}$} \\
\hline & & $\begin{array}{c}\text { Nitrite } \\
\text { found }(\mu \mathrm{g})\end{array}$ & $\begin{array}{l}\text { Mean } \\
\text { recovery }\end{array}$ & $\begin{array}{c}\text { Nitrite } \\
\text { found( } \mu \mathrm{g})\end{array}$ & $\begin{array}{c}\text { Mean } \\
\text { recovery }\end{array}$ \\
\hline Kukarally lake $^{\mathrm{a}}$ & - & 0.1 & - & Not found & - \\
\hline Industrial effluent & - & 4.0 & - & 3.99 & - \\
\hline \multirow[t]{3}{*}{ Tap water ${ }^{b}$} & 0.5 & 0.5 & 100 & Not found & - \\
\hline & 2.0 & 1.99 & 99.5 & 1.97 & 98.5 \\
\hline & 3.0 & 2.98 & 99.3 & 2.98 & 99.3 \\
\hline
\end{tabular}

a. Eutrophic lake.

b. Tap water gave no test for nitrite. 


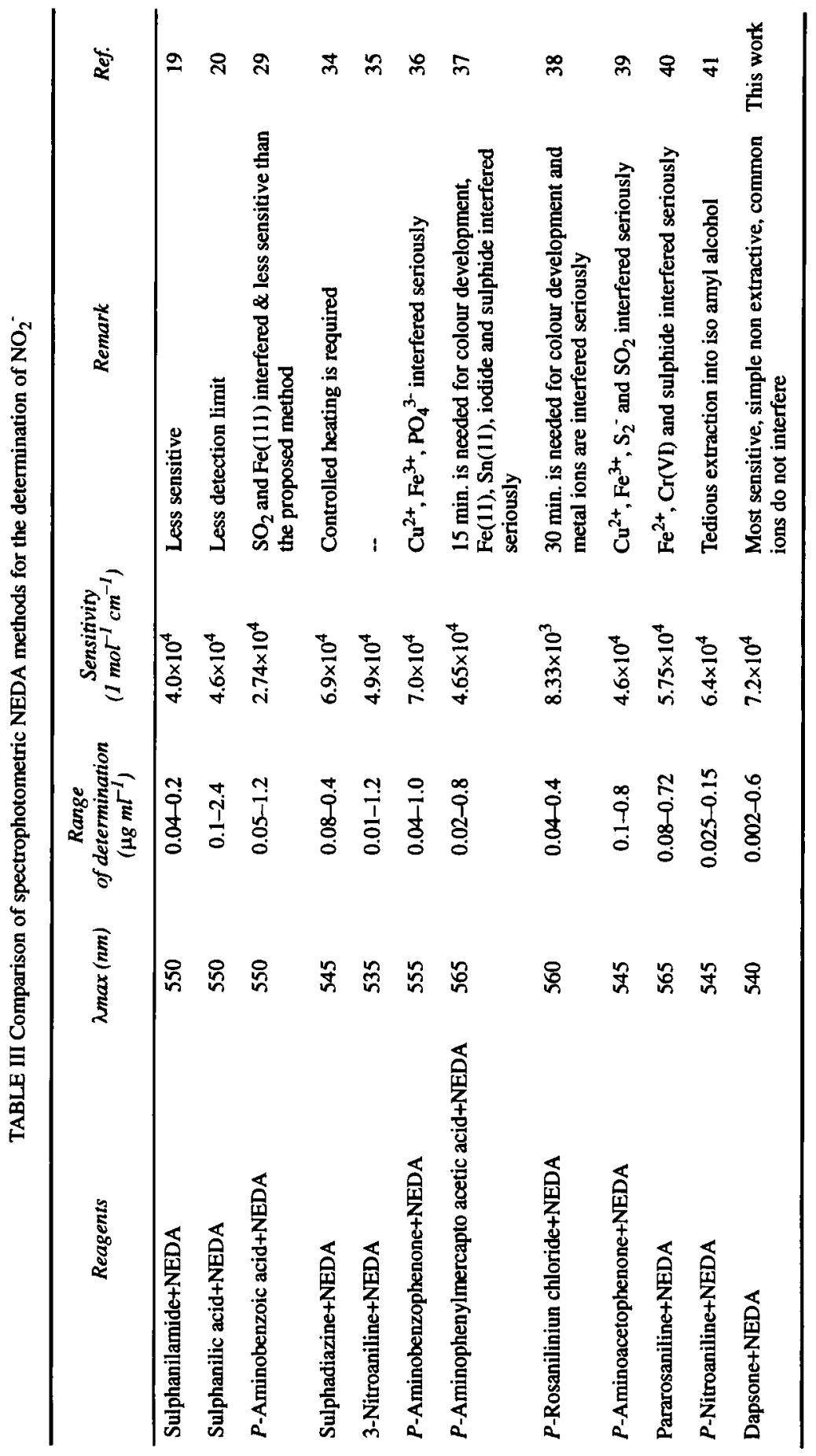




\section{Qualitative analysis}

The diazotization-coupling test is the most distinctive qualitative test for nitrite, as no other anion diazotizes and couples. Using separate solutions, the following diazotization coupling combinations have been used as a qualitative test for nitrite: Sulphanilic acid and 1-Naphthylamine ${ }^{[31]}$, Sulphanilic acid and $\mathrm{NEDA}^{[20]}$, aniline sulphate and 1-Naphthol ${ }^{[32]}$ and sulphanilic acid and 1-Naphthol ${ }^{[32]}$. It is recommended that the dapsone-NEDA reagent described here can be used as a qualitative test. The sulphanilic acid-NEDA reagent is not recommended because of the marked effect of interferences. The 4-Nitroanaline-NEDA reagent should not be used as a qualitative test because the yellow colour of the 4-nitroaniline may obscure visual observation. In the application of dapsone-NEDA reagent as a qualitative test, a few drops to $1.0 \mathrm{ml}$ of reagent should be added to an equal volume of solution. A standing time of $2 \mathrm{~min}$ is required, the pink colour develops very rapidly when the ratio of reagent to sample is high.

\section{Sample storage}

Acid preservation method should not be used for analysis of $\mathrm{NO}_{2}^{-}$in samples. The determination should be conducted on fresh samples to prevent bacterial conversion of $\mathrm{NO}_{2}^{-}$to $\mathrm{NO}_{3}{ }^{-}$or $\mathrm{NH}_{3}$. For short term preservation for 1-2 days, freeze at $20^{\circ} \mathrm{C}$ or store at $4^{\circ} \mathrm{C}$.

\section{Conclusion}

The results clearly indicate the utility of the proposed method for the analysis of various water samples. The present method is highly sensitive than the reported methods which involves NEDA as a coupling agent. The rapid colour development, excellent Beer's law curve and reproducibility, as well as freedom from interference by a large group of foreign ions are advantages of this method. This method requires neither extraction nor heating.

\section{Acknowledgements}

The authors are grateful to the University of Mysore, Mysore, for providing laboratory facilities. One of the authors (M.S. Hemantha Kumar) thanks the coordinator, Department of Environmental Science, University of Mysore for the cooperation extended to this research work.

\section{References}

[1] F.A. Pattay, Industrial Hygine and Toxicology, (Interscience, NewYork, 1963), 917pp. 
[2] W. Lijinsky and S. Epstein, Nature (London), 21, 225-227 (1970).

[3] Z. Knotek and P. Schmidt, Pediatrics, 34, 78-80 (1964).

[4] P. Magee and J. Barnes, Br. J. Cancer, 10, 114-116 (1956).

[5] I. Wolff and A. Wasserman, Science, 177, 15-19 (1972).

[6] S.A. Abbasi, Water Quality Sampling and Analysis, (Discovery Publishing House, New Delhi, 1998), $191 \mathrm{pp}$.

[7] American public Health Association and water pollution control Federation, Standard Methods for the Examination of Water and Waste water, (American Public Health Association, New York, 1975), 14 ${ }^{\text {th }}$ Ed., 434pp.

[8] C. Garcide, C. Mar. Chem., 11, 159-167 (1982).

[9] J.Y. Zhou, P. Prognon, C. Daulphin and M. Homan, HPLC Flurocent Chromatogr., 36, 57-60 (1993).

[10] N.J. Princeton, Princeton Applied Research, Application Brief N-1, (1974).

[11] E. Wada and A. Hattori, Anal. Chim. Acta, 56, 233-240 (1971).

[12] J.L. Manzoori, M.H. Sorouraddin and A.M. Shabani, Talanta, 46, 1379-1386 (1998).

[13] Z.Q. Zhang, L.J. Gao, H.Y. Zhan and Q.G. Liu, Anal. Chim. Acta, 370, 59-63 (1998).

[14] Z.Q. Zhang, L.J. Gao and H.Y. Zhan, Talanta, 47, 497-501 (1998).

[15] B. Liang, M. Iwatsuki and T. Fukasawa, Analyst, 119, 2113-2117 (1994).

[16] L. Anderson, Anal. Chim. Acta, 110, 123-128 (1979).

[17] M. Nakashima, M. Yagi, A. Zenki, K. Takahashi and K. Toei, Anal. Chim Acta, 155, 263-268 (1983).

[18] P. Griess, Chem. Ber., 12, 427-428 (1879).

[19] B.E. Saltzman, Anal. Chem., 26, 1949-1955 (1954).

[20] M.B. Jacobs and S. Hochheiser, Anal. Chem., 30, 426-428 (1958).

[21] B.G. Liptak, Environmental Engineers Hand Book, (Chilton Book Co., Pennsylvania, 1972), $62 \mathrm{pp}$.

[22] C. Chimnescu and V. Domeanu, Talanta, 19, 1474-1476 (1972).

[23] Y. Cai and Z. Hu, Huaxue-Shiji., 11, 73-74 (1989).

[24] A.K. Baveja and V.K. Gupta, Chem. Anal., 28, 693-699 (1983).

[25] E.E. Garcia, Anal. Chem., 39, 1605-1607 (1967).

[26] Qian-Feng Wu and Peng-Fei Liu, Talanta, 30, 374-376 (1983).

[27] M. Satake and G.F. Wang, Fresenius J. Anal. Chem., 357, 433-438 (1997).

[28] T. Kawakami and S. Igarashi, Anal. Chim. Acta, 333, 175-180 (1996).

[29] P. Nagaraja, M.S. Hemantha Kumar, K.S. Rangappa and L. Mahesh Bilwa, Oriental Journal of Chemistry, 14, 55-58 (1998).

[30] P. Nagaraja, M.S. Hemantha Kumar, K.S. Rangappa and A.S. Suresh, Asian Journal of Chemistry, 11, 509-514 (1999).

[31] H.H. Barber and T.T. Taylor, Semimicro qualitative analysis, (Harper and Brothers, New York, 1953), pp. 55-62 and 337,.

[32] F. Feigl and V. Anger, Spot tests in Inorganic Analysis, (Elsevier, New York, 1972), $6^{\text {th }}$ Ed., pp. 364-365,

[33] R.E.D. Clark, Qualitative Inorganic Analysis, (Pergamon Press, New York and London, 1965), 92pp.

[34] S.S. Nair, Intern. J. Environ. Anal. Chem., 44, 153-158 (1991).

[35] H.P.S. Rathore and S.K. Tiwari, Anal. Chim. Acta, 242, 225-228 (1991).

[36] A.A. Al-Hatin, Intern. J. Environ. Anal. Chem., 38, 617-622 (1990).

[37] P.K. Tarafder and H.P.S. Rathore, Analyst, 113, 1073-1076 (1988).

[38] V. Raman and C.P. Sharma, J. Indian Chem. Soc., 66, 840-841 (1989).

[39] P. Kaur, S. Sunitha and V.K. Guptha, J. Indian Chem. Soc., 64, 428-430 (1987),

[40] A.K. Baveja and V.K. Guptha, Chem. Anal., 28, 693-699 (1983).

[41] Abha Chaube, A.K. Baveja and V.K. Guptha, Talanta, 31, 391-393 (1984). 